\title{
A Visit to a Greater Prairie Chicken Booming Ground
}

\author{
By Kathleen Hodges, Calgary
}

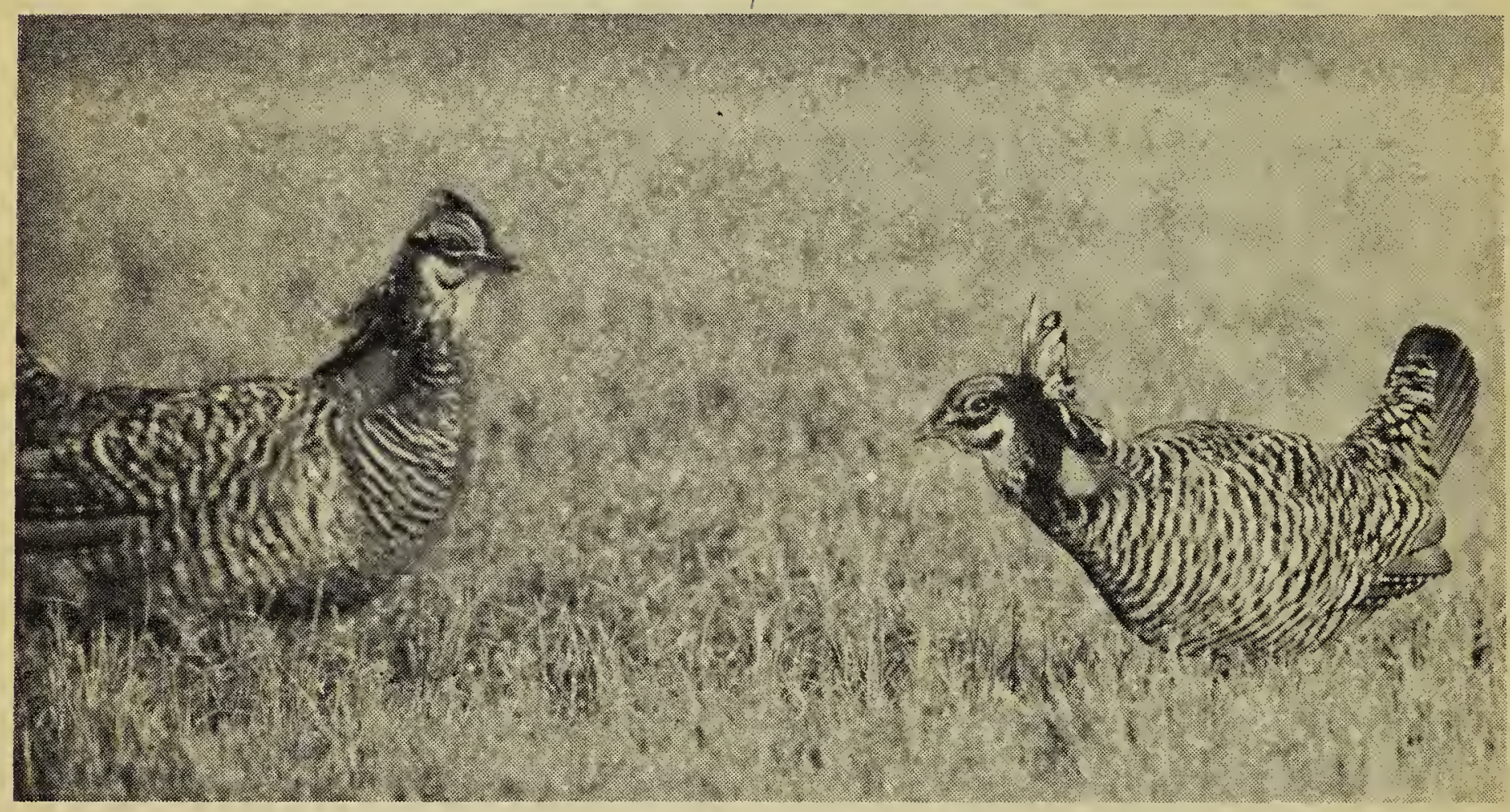

Photo by K. Hodges

GREATER PRAIRIE CHICKEN ON BOOMING GROUND

Booo ah ooom - booo ah ooombooo ah ooom! This was the sound that I had travelled over a thousand miles across the prairies to hear. This sound was enough to convince me that the trip in chilly April was worthwhile. Watching Prairie Chickens on their booming grounds from a few feet for the first time was a wonderful experience not soon to be forgotten. For a day or two, at this booming ground in Minnesota, the North Star State, Spring managed to push Winter aside.

Contrary to what I had read, this booming ground-the first I had ever visited-was not on a rise or eminence of land or a bare knoll, but was in a shallow depression, immediately behind what is known as the Campbell shoreline, the most recent shoreline of ancient Lake Agassiz. In this slight depression, surrounded by bluffs of willows, elm, poplar, dogwood and other shrubbery, were two small temporary sloughs through which the closely cut hay was only just beginning to peek. Minnesota, a Sioux Indian word, is poetic, meaning sky-tinted water or cloudy water. This then was a perfect setting for the Prairie Chicken booming ground, between two sky-tinted sloughs reflecting the clouds:

Two hours before the sun gleamed above the horizon the birds had already gathered on their ancestral booming grounds, and in the light of the full moon, their shadowy forms could only just be detected. Some returned by flying directly to the territory which they claimed. Some advanced slowly, sometimes unconcernedly walking through the shallow, sky-tinted water. The constantly repeated, low, undulating, resounding booming started soon after their arrival. Though the booming is low it is loud and it is said to carry a distance of two miles on a calm morning. In my position in the middle of the booming area, it was, at the height of the booming, like being suspended in the centre of a large base drum while the drummer rhythmically rolled and beat the drumsticks across its surface. Interjected in the booming chorus were many high-pitched "ca-cas" made by the birds as they took up their positions, and these sounded like noises made by an excited but restrained chicken 
in its effort to escape. These unusual "ca-cas" carry far in the morning stillness, and some people can hear them before the booming.

When the males dash at one another along tiny, well-worn paths to meet on territorial borderlines, they greet each other with a grunt. The spectacular orange-like air sacs in the neck are inflated, the pinnate feathers which normally lie along the neck are raised vertically above the head, the feathers of the tail are fanned out and stiffly erected and the wings are spread and drooped to the side. They then have the amusing appearance of rabbits preparing for the next jump, head held low and body hunched up. Their dancing feet make an unusual pattering sound as they run to and fro on the damp ground. As I watched two females strode across the extensive booming area and booming increased in tempo; I was then favoured to hear and see these birds at their ultimate best. There was much excitement as the male birds on the outskirts moved in. Territories became divided and subdivided as more birds sought to establish themselves closer to a female. These new territories were only gained after prolonged fights which saw feathers fly. The male bird within whose territory the fe- male lingered became very active and threatening on the approach of any other birds. $\mathrm{He}$ was a large handsome male and was thoroughly successful in his home-defence program and capable of retaining a fairly large area. Birds outside of the territory of the fiavoured male frequently jumped into the air with a slight flutter of wings and a harsh cackle, in an apparen't effort to attract the female. This action seemed to have no effect on the nonchalant female.

At one point, when the birds became silent and motionless, I looked around as much as I could from my confined space and happened to see a Marsh Hawk make a pass at one of the birds. The Prairie Chicken flew off but returned shortly afterwards.

While waiting in a blind one sometimes witnesses amusing incidents. One afternoon while thus waiting I could see some children with their dog approaching my Volkswagen bus parked beside a haystack on the shoreline ridge above the booming grounds. School was apparently out and they had come along on an inspection tour. Their first stop was my bus where they climbed upon the bumpers front and back and gave it a thorough inspection inside and out. A consultation followed, they looked

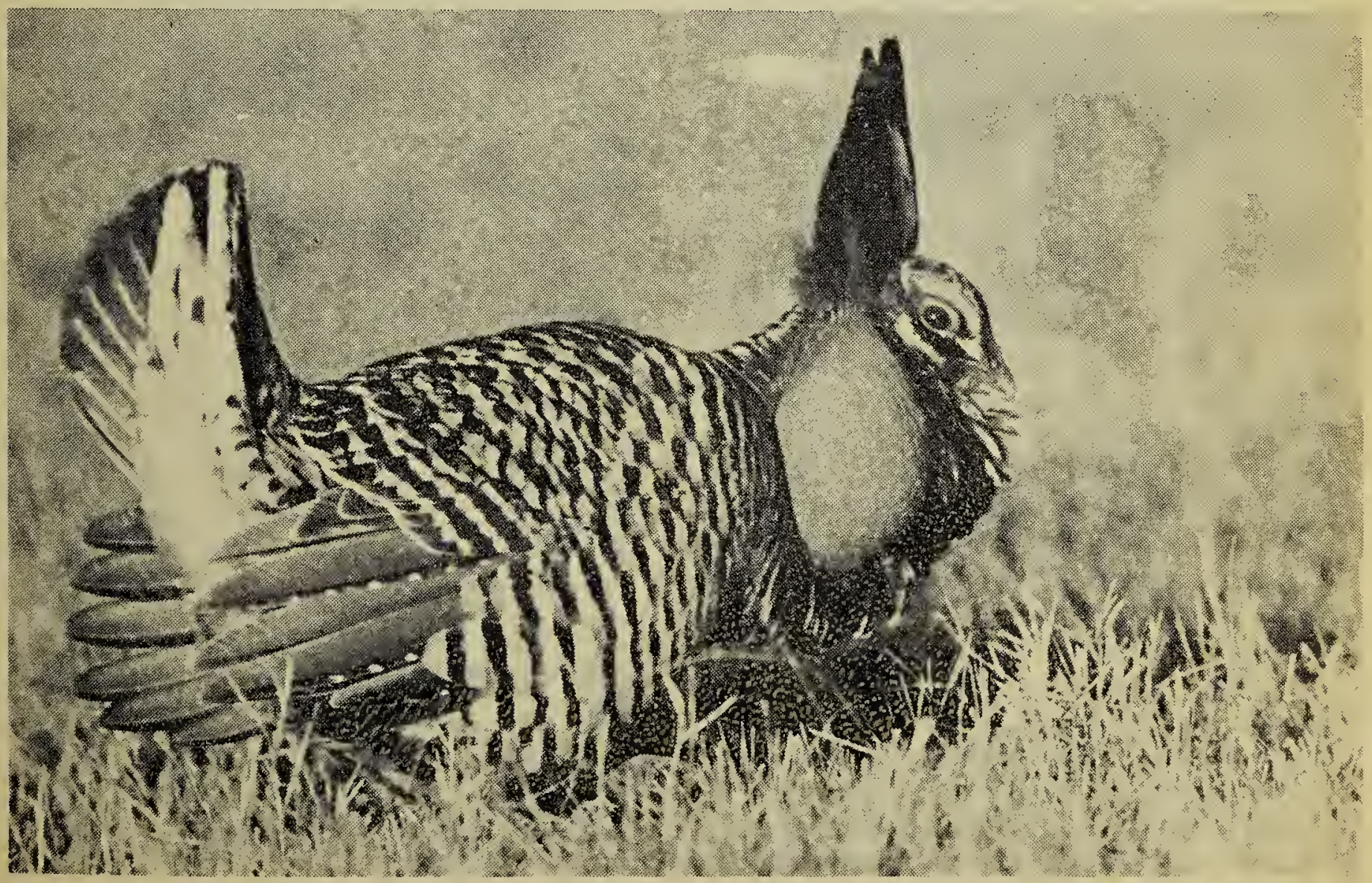


and pointed towards my blind and then headed in its direction. It looked as if my hide-out would be their second stop. I watched them pick their way carefully around the slough in an effort to keep their shoes dry. There were four and they ranged in age from five to eight. As they came closer I heard one say, "It looks like it's made of cardboard" and other indecipherable remarks. As they got within speaking distance, the boy of the group boldly said, "Anybody home?" I had withdrawn my telephoto lens as the boy was carrying a stick and I didn't know just what to expect. He said again, "Anybody there?" to which I answered with a "Yes!" I guess they didn't expect the blind to be, inhabited, and with a few startled gasps they took to their heels and didn't stop until they got back up on the ridge some distance from the bus. Nor did they pick their way carefully around the slough, but headed straight through the middle. It was the most direct route towards home. Home I believe was their third stop. I guess I was as surprised as they at this reaction and I chuckled as I looked out of the peep-hole and saw them splashing their way through the slough.

Spring on the prairies comes late. Bursting tree buds and a lush growth of grass are not visible until late May. But the first signs of Spring are evident in April and I noted Flickers arriving daily for a brief stop-over in migration, as many as a dozen being seen at one time clumsily walking over the hay meadow, or flitting through the trees. Western Meadowlarks were singing from vantage points.

In North Dakota another booming ground was visited where the birds executed their elaborate and interesting mating ritual on newly ploughed land, an adaptation that was unexpected. Wherever their booming grounds may be, the birds all seem to leave their chosen spot soon after day-break.

Formerly found from the Atlantic States through the Great Plains of North America, they are now confined largely to the Great Plains regions. This is the bird to which, by precedence and by custom, rightfully belongs the name Prairie Chicken. From the long feathers on its neck it has also received another namePinnated Grouse. And to distinguish it from the Sharp-tailed Grouse, it is sometimes called the Square-tail. It is larger and darker than the Sharptail and the inflated air sacs, seen only during the dancing ritual, are a vivid orange rather than lilac as in the Sharp-tail.

In my notes of birds seen on this thoroughly enjoyable holiday, Marsh Hawks predominate. A rather remarkable flight of Snow Buntings was witnessed west of Winnipeg, where several flocks containing thousands of these birds flew across the ploughed fields. The fields were a rich black, still wet from the melting winter snows, and against this background the "snow birds" made a charming sight, looking like large fluffy snowflakes that come with a spring snowstorm. The warm welcomes with which I was everywhere received contrasted sharply with the exceptionally cold April weather, and I am indeed most grateful to the many folks who helped me in so many ways on this trip.

\section{DETERMINED DANCERS}

\section{By Lindsay Wotherspoon, Crestview, Man.}

We have a Sharp-tailed dancing ground on our farm and 20 to 25 birds congregated there last spring. As I was seeding the field on May 27, 1959, I seeded right through their acre-sized "dance hall," but they did not interrupt their manoeuvres except to keep out of the way of the tractor and drill. I watched the birds so intently that I made some pretty crooked seed rows.

Our farm is at the northern edge of settlement, on the edge of the Porcupine Mountains, 20 miles north and four miles east of Arran, and just one and a half miles west of the Manitoba border ( $\mathrm{N} 1 / 2$ 11, T.37, R. 30, W. 1). The farm is really in Saskatchewan though we get our mail at a Manitoba post office, Crestview. 